\title{
Introduction to Post-Keynesian Growth Theory
}

\author{
Marc Lavoie
}

\section{Early thoughts}

My first encounter with post-Keynesian growth theory was during the 1975-76 Honours Seminar in Modern Classics, which was a compulsory full-year undergraduate course in Economics at Carleton University, located in Ottawa, given by Thomas K. Rymes. The Seminar touched diverse fields in economics, ranging from Walrasian exchange and production theory, as well as neoclassical growth theory, and then moving on to the monetary framework with Keynes, Patinkin, Clower, Leijonhufvud and Friedman. Other professors also gave occasional lectures, for instance on the theory of the firm, the principal/agent distinction, shirking by workers and the theory of capital markets. Rymes had done his $\mathrm{PhD}$ at McGill University, in Montreal, which at the time and until the early 1980s was the main centre of Cambridge-style Keynesian economics, from which Canadian colleagues such as Mario Seccareccia, Louis-Philippe Rochon, Omar Hamouda, Gilles Dostaler and Morris Altman graduated at either the MA or PhD level. Rymes devoted two lectures to the Cambridge capital controversies (reswitching and capital reversals in two-sector models) and productivity accounting in December 1975. I only found out a year later, when browsing through shelves in a London bookstore, that he had written a whole book on the Cambridge controversies and its implications for productivity measurement, with a very favourable preface by none other than Joan Robinson (Rymes, 1971). He started the 1976 lectures by tackling Harrod's growth model and the neo-Keynesian or neo-Cambridgian models as they were then called. These were the models proposed in the mid-1950s and early 1960s by Joan Robinson, Nicholas Kaldor and Luigi Pasinetti.

Like many students, I suppose, I was fascinated and puzzled by Pasinetti's long-run solution to the macroeconomic determination of the profit rate, $r=g / s_{c}$, which only depended on the growth rate of the economy and the propensity to save of capitalists, regardless of the propensity to save of workers. So much so that when I moved to the University of Paris 1 Panthéon-Sorbonne for my graduate studies in the Fall of 1976, my first major paper was devoted to 'L'introduction de la firme et de la finance dans le modèle de croissance et répartition de Pasinetti' (The introduction of the firm and of finance in Pasinetti's model of growth and distribution), which also discussed Kaldor's neo-Pasinetti theorem. I elected to write my doctoral dissertation on a topic closer to monetary economics, however, and so my main interest became the post-Keynesian theory of endogenous money. When I got a position at the University of Ottawa (first, as a temporary position in 1979, then a tenure-track one in 1981), I opted to teach the graduate course in growth economics, and my lecture notes gave rise to my 1987 book, Macroéconomie: Théories et controverses postkeynésiennes (Macroeconomics: Post-Keynesian Theories and Controversies), which dealt with the Cambridge controversies, in particular its implications for the measurement of technical progress and the national accounting identity problem when testing neoclassical production functions, a problem that had been underlined by Anwar Shaikh and Herbert Simon. ${ }^{1}$ The rest 
of the book mainly discussed newer post-Keynesian growth models and their institutional extensions, for instance the model of Adrian Wood (1975) and various versions of the neoPasinetti theorem.

The first chapter of the second half of the book, devoted to the post-Keynesian alternative, examined the foundations of post-Keynesian macroeconomics. The chapter dealt with the shape of cost curves, the claim that firms usually operate at a normal rate of capacity utilization which is much below full-capacity utilization, and the distinction between direct and overhead workers which had been underlined by both Tom Asimakopulos (1975), who was then a professor at McGill University, and by Donald Harris (1974), the father of US Vice-President Kamala Harris. Harris was a professor at Stanford University, who taught well-known postKeynesians like Robert Blecker, Steve Fazzari and the late Tracy Mott.

Whereas the post-Keynesian models of the 1950s and early 1960s relied on changes in profit margins at normal capacity utilization to explain the positive relation between profit rates, profit shares and the rate of accumulation, faster growth at higher rates of utilization could explain the positive relation between profit shares and growth without changes in profit margins, thanks to the presence of overhead labour. However, just like Fernando Vianello (1985), whom I had met at the Trieste Summer School in 1984, I could not fathom how the relation between the growth rate and the profit rate could keep holding while the economy would revert back to a normal rate of utilization with a faster rate of accumulation. How the transition could actually be achieved, as I noted then, was a most interesting problem, especially in a two-sector model. That was the problem of the so-called traverse. Surprisingly it seems, I only became aware of the papers on the neo-Kaleckian model of growth and distribution shortly after my book came out, when I attended the 1987 Kaldor conference held jointly at the New School and at the Levy Economics Institute. Reading the papers by Robert Rowthorn (1981) and Amitava Dutt (1984), with their endogenous rate of utilization, both in the short and the long run, was a revelation.

I quickly integrated the neo-Kaleckian models in both my undergraduate course on postKeynesian economics and in the graduate course on growth. The lectures gave rise to my 1992 book, Foundations of Post-Keynesian Economic Analysis (Lavoie, 1992). Usually, colleagues first publish papers in journals and later adapt them and link them to form a book. I proceeded the other way around. My interpretation of the various controversies and discussions surrounding the neo-Kaleckian model first appeared in the 1992 book (the writing of which was finished in September 1991), and it is only later that I produced and submitted articles around this topic. The only exception is a presentation that I made at a conference organized by Gary Mongiovi and Christof Rühl (at the time a student of Harald Hagemann and Heinz Kurz), at the University of Hohenheim in Stuttgart, in July 1990 (Lavoie, 1993). The conference had a remarkable format: each of us had nearly an hour to present and the question period lasted 30 minutes. Except for Malcolm Sawyer (!), all the participants were (relatively) young economists: Arie Arnon, Avi Cohen, Christian Gehrke, Chidem Kurdas, Fiona Maclachan, Juan Carlos Moreno Brid, Marco Musella, Carlo Panico, Fabio Petri, Peter Skott and Hans-Michael Trautwein. I presented what I called a post-classical model of growth, in an attempt to integrate Kaleckian, Sraffian and Eichnerian views. The rate of accumulation was a function of the rate of utilization, the profit share and the difference between the profit rate and the interest rate. The profit share itself was a positive function of the power of firms, the growth rate and the interest rate, while the saving function split corporate retained earnings 
from saving by households. The conditions of the effect of changes in the exogenous part of the profit share and in the interest rate were derived by using the Maple software, which seems to have impressed the participants at the time!

The above thus should help to understand how I got involved in developing models of growth and distribution, despite monetary theory and policy being my main field of research, and despite having ventured into other fields, such as sports economics (with two books and about 25 papers) and language economics (half-a-dozen papers). I am grateful to Alan Sturmer from Edward Elgar for giving me the opportunity to collect in a single volume the main papers that I have written on the topic of growth and distribution. I have tried to avoid repetitions as best as I could when making the selection. I also need to thank Louis-Philippe Rochon for having suggested this endeavour and for having collected the permissions necessary for reproduction.

\section{Part I: Basic Kaleckian models of growth and distribution}

The first chapter in Part I of this book, devoted to the basic Kaleckian models of growth and distribution, was published in 1995 in the Cambridge Journal of Economics. It is one of my five most cited articles (according to Google Scholar). It presented the critiques that Sraffian and Marxian authors were already addressing to the newly-created neo-Kaleckian model, attempting to present some justifications or counter-arguments. As Eckhard Hein recalls in his foreword, the response to these earlier critiques and to more recent ones was extended half-adozen years later in two joint papers, found in Hein et al. $(2011,2012)$.

One of those possible responses was that the normal rate of utilization could itself be influenced by the current rate of utilization - a form of hysteresis. This is the topic of Chapter 2, the 1996 Review of Radical Political Economics article. This proposition is highly controversial still today and it has given rise to several theoretical and empirical works. It was alluded to in the previous 1995 paper, which explains why some authors refer to it when discussing an endogenous normal rate of utilization, but the proposition and its hysteresisbased traverse is much better developed, depicted and formalized in the 1996 article. One of the intents of the article is to question Duménil and Lévy's (1995, p. 136) statement to the effect that 'while it is possible to be Keynesian in the short term, one is required to be classical in the long term'. I must say that Gérard Duménil and Dominique Lévy were very gracious since they had helped me in formalizing the details of the model that intended to disprove their claim. There is an error in the acknowledgment footnote: the paper was not first presented in March 1993 but rather in March 1995, when I was visiting Curtin University, replacing Phil O'Hara for six months. This gave us an opportunity, me and my spouse Camille, to visit her sister who was then living in Perth, and for our three children to see their three cousins within their Australian environment. At the end of the six months, however, I felt that the French of the cousins had greatly improved while the English of my kids had only made moderate progress!

Chapter 3, a paper published in the 2003 Review of Political Economy, was another effort, after the 1993 chapter, at integrating the Sraffian views with the Kaleckian ones, while also questioning Duménil and Lévy's statement about the need to be classical in the long run. It points to the similarities between the Sraffian normal rate of the profit and the target rate of return in pricing theories à la Lanzillotti (1958). This paper focuses on the role of the rate of interest in determining the target rate of return of firms, but also on the consequences of 
assuming that the target rate of return is being influenced by the actual rate of profit. The crux of the paper, found in its latter sections, is the integration of a conflicting-claims theory of inflation to this endogenized target rate of return. Within this framework, the actual profit rate will become equal to the target rate of return desired or assessed by firms, but at a rate of utilization that in general will be different from the normal or standard rate of capacity utilization. Thus, with the addition of conflict inflation, the rate of capacity utilization remains endogenous in the long run.

The 2009 Review of Political Economy paper (Chapter 4) focuses on the consequences of taking overhead labour into account. The title 'Cadrisme within a post-Keynesian model of growth and distribution', is inspired by the use of the word 'cadrisme' by Duménil and Lévy when describing modern capitalism with its well-paid managers. The paper was published in a special issue in honour of Nicholas Kaldor, and I thought it was fitting to underline the fact that Kaldor, already in 1964, had remarked that an expansion of output would lead to a higher profit share despite holding constant the markup on direct costs, on account of overhead costs. The main purpose of the paper was to go beyond Dutt (1992) and Rowthorn (1981), who had integrated overhead labour within their model, but without taking into account the possibility that firms would raise their markups whenever overhead labour costs would be on the rise, in an attempt to pass onto consumers this cost increase. Once again, the crux of the matter is the assumption that firms follow target-return pricing and hence pursue a target rate of return; they wish to obtain a normal rate of profit when the firm is operating at the standard rate of capacity utilization. I had tackled this topic in a previously published paper (Lavoie, 1996), but with little impact, and hence I believed it was worth giving it another go in a slightly different way.

The presence and importance of overhead labour in our economies and in the empirical debate over whether countries are in a wage-led or profit-led regime is the theme of the fifth chapter of Part I, published in the 2017 European Journal of Economics and Economic Policies: Intervention. This is another topic of contention among heterodox economists, with most Marxian-influenced post-Keynesian authors, of a Goodwinian pedigree, usually believing or finding that economies have a profit-led demand with a profit-squeeze mechanism, while Kaleckian authors believe or find that countries are in a wage-led demand regime, or at least that domestic demand is wage led (by contrast to total demand, including net exports, which may be profit led). Besides the rate of utilization, the controversies extend to rates of accumulation, employment and productivity. The paper shows that debates over whether demand is wage led or profit led have been going on for a long time, sometimes in a confusing way, but that some earlier contributions are worth reading again. The main point of the paper is that the presence of overhead costs, ever more important today, may give the false impression under some empirical methods, that demand is profit led. This is because, as pointed out earlier, with a given markup, an increase (decrease) in economic activity will raise (lower) the profit share. A clear example of this occurred at the beginning of the Covid-19 pandemic and lockdown: as production faltered, the wage share in the USA and in Canada went up by almost ten percentage points. Goodwinians would have said that the steep rise in the wage share provoked a drastic fall in economic activity!

The next three chapters of Part I focus on the role of money and finance within growth models. The title of the 1995 Metroeconomica paper (Chapter 6) is explicit: 'Interest rates in post-Keynesian models of growth and distribution'. The paper sets forth a series of models 
where the interest rate would play a role. At the time there were relatively few contributions putting together the post-Keynesian theory of endogenous money and growth theory. As Eckhard Hein mentioned in his foreword, the various models found in the article were an inspiration for a whole series of articles of his, which were gathered in particular in his book Money, Distribution Conflict and Capital Accumulation: Contributions to Monetary Analysis (Hein, 2008). The paper was initially based on some of the analysis found in my 1992 book and in the Hohenheim chapter, but the Italian referees provided highly useful comments, as well as suggestions for changes and simplifications, which led to a completely revamped paper and one additional model. This was my Minsky-Steindl model, found in section 5 of the paper, which had symmetric saving and investment functions, and where the corporate debtto-capital ratio could exhibit dynamic stability or instability. Of particular interest, in one of the configurations, dynamic instability entailed an endogenous (anti-Minskyan or Steindlian) negative relationship between the debt ratio of firms and their rate of accumulation.

I mentioned earlier that I had been mesmerized by Pasinetti's Cambridge equation, and also fascinated by Kaldor's neo-Pasinetti theorem, which came to a similar conclusion, namely that the propensity to save of households had no impact on the macroeconomic profit rate. In my 1987 French book, I had devoted a whole chapter to the neo-Pasinetti theorem and its valuation ratio (similar to Tobin's q ratio), linking it to the work of Richard Kahn, Robin Marris and Scott Moss. While the neo-Pasinetti theorem of 1966 had generated several comments in its days, it had been more or less ignored until Jorge Araujo (1995) gave it a new look. This attracted my attention and I decided to see how it could be set within a neoKaleckian model with an endogenous rate of utilization. This became the 1998 article published in the Eastern Economic Journal (Chapter 7). One of the key lessons was that an exogenous increase in the growth rate, with an endogenous rate of utilization, under weak conditions, did not lead to a decrease in the valuation ratio, in contrast to the standard interpretation of the neo-Pasinetti model assumed to be stuck at its normal level of capacity utilization, where an increase in investment and a decrease in the propensity to save of households always led to a fall in the valuation ratio. Hence, even if firms had investment functions incorporating the valuation ratio, it could still be argued that firms are free to accumulate as they please within wide limits, as Joan Robinson had earlier claimed.

One drawback of the neo-Pasinetti model is that even though the valuation ratio is supposed to be associated with an implicit interest rate (in an inverse relationship, as shown by Richard Kahn, 1972), there is no money in the model. All savings are made in the form of purchases of stock market shares, a drawback that was quickly noted by Paul Davidson (1968). The obvious amendment is thus to add money deposits to the portfolio choice of households. This I attempted to achieve in a paper that I submitted, but the referees were quick to point out that I was mishandling capital gains. As we say in French, this was un mal pour un bien, because I asked Wynne Godley, whom I had met a few months before, to help me with this accounting issue. It led to nearly ten years of collaboration with Wynne, first on this enhanced neo-Pasinetti model (Lavoie and Godley, 2001-02), and then on the book describing the stock-flow consistent approach (Godley and Lavoie, 2007).

The last paper of Part I (Chapter 8) was written with Peter Kriesler when he came to the University of Ottawa on a sabbatical with his family for a few months during our Summer. In fact, his visit was a very productive affair since we ended up publishing three papers together. The paper chosen here to illustrate our collaboration appeared in the 2007 Review of Radical 
Political Economics. Its main purpose was to show that the Duménil and Lévy (1999) heterodox macroeconomic model ended up having the same properties as the mainstream 3 -equation model that was so popular in academia at the time, and which can be found in most mainstream macro textbooks today. The 3-equation model, also called the New Consensus, as is well known through the writings of Philip Arestis (2009), has attracted the attention of several post-Keynesian economists, as found in the book edited by Giuseppe Fontana and Mark Setterfield (2009), because it relies on a central bank reaction function that determines the interest rate, being implicitly assumed that the supply of money and bank reserves are endogenous. I had myself designed a closed four-quadrant illustration of the New Consensus, and provided a post-Keynesian amendment of it, introducing path dependence and hysteresis, thus showing that inflation targeting could bring about a negative impact on the real economy both in the short run and in the long run, in contrast to the claims of the New Consensus (Lavoie, 2006). Coming back to Duménil and Lévy, Kriesler and I showed that their model behaved in a way that was analogous to the Consensus View. In addition, their model also reproduced the lessons that could be drawn from the supply-led New Endogenous Growth theory. Our approach was vindicated when I presented the paper at the University of Paris 13, with Dominique Lévy in attendance, who recognized that indeed their model seemed to be isomorphic to that of the New Consensus. Our point then, was that if anybody is on the lookout for some alternative to the Washington Consensus, it was unlikely to be found within Marxian macroeconomics.

\section{Part II: Kaleckian models with autonomous non-capacity creating expenditures}

One of the main criticisms addressed to the basic neo-Kaleckian model, or for that matter to the post-Kaleckian model of Bhaduri and Marglin (1990) and Kurz (1990), is that the rate of capacity utilization does not converge to its normal value in the long run. The critique is that firms will not allow their rate of utilization to forever diverge from what they consider to be the normal or optimal rate; at the very least the actual rate should cycle around the normal rate. Related to this was the critique that the neo-Kaleckian model would fall prey to Harrodian instability - Harrod's principle of dynamic instability - as firms tried to correct the situation. Another critique is that whereas the neo-Kaleckian model pretends that an increase in the wage share leads to an increase in the growth rate, most empirical studies look at the shortterm effects of a change in the wage share, and hence, in the case of a wage-led economy, assess that an increase in the wage share leads to an increase in the level of economic activity; but they do not demonstrate that such an increase in the wage share leads to an increase in the growth rate of economic activity.

In 2012, Olivier Allain, who had previously written a synthesis on the neo-Kaleckian model of growth and distribution for the French public, sent me a working paper of his where he offered a response to all three of these criticisms. He combined standard Kaleckian investment and saving functions with an autonomous government expenditure growing at a constant rate, adding to these a Harrodian instability mechanism. Surprisingly, under weak conditions, this combination produced a model where the economy converges to its normal rate of capacity utilization, with the standard properties of the neo-Kaleckian model being reproduced provided they were interpreted in levels rather than in growth terms (Allain, 2015). In other words, an increase in the wage share would produce a temporary acceleration in the growth rate of economic activity, which would then come back to the exogenous growth rate set by 
government expenditures. The increase in the wage share would thus lead to permanent rise in the level of economic activity and in productive capacity. The same would happen with a decrease in the saving rate.

When I read Allain's paper I realized that there was a great degree of similarity with the so-called Sraffian supermultiplier approach which had been put forward by Franklin Serrano (1995), Graham White (1996) and Heinrich Bortis (1997), and I alerted Allain to the similarities. Their argument was that firms adjust their production capacity to secular or trend effective demand, and hence, provided there is no persistent mistake in the assessment of long-term demand expectations, there is a tendency for the economy to grow on average at the normal rate of capacity utilization. I had encountered again this argument when I participated, in May 2002, in a workshop organized by Amitava Dutt at the University of Notre Dame, when Serrano had presented a version of his model, and then again at the Sraffa conference that had been organized at the University of Roma Tre in 2010, when Óscar Dejuán (2013) had presented arguments to that effect. At the time I felt that there was no coherent dynamic mechanism that would explain how one would get from some arbitrary rate of utilization towards the normal rate of capacity utilization. ${ }^{2}$ Serrano and Freitas (2007), in a paper published in Spanish, provided the mechanism that could bring the economy towards the normal rate of utilization. This mechanism was the combination of a non-capacity-generating autonomous consumption component, thus making the average propensity to save endogenous as argued previously by Serrano (1995), with a flexible accelerator model of induced investment, where the share of investment in output increases whenever the actual rate of utilization is higher than the normal rate. While all the ingredients were present in that paper, it did not provide a formal stability proof of the mechanism. This proof was finally delivered in the paper of Freitas and Serrano (2015), and has since given rise to an expanding empirical and theoretical literature in support of the Sraffian supermultiplier.

Allain's autonomous expenditure in his Kaleckian growth model was government expenditure, so I thought it would be interesting to follow the line pursued by Serrano and introduce instead an autonomous consumption component in the Kaleckian model, along with the Harrodian instability mechanism, as Allain had done, and see what would happen. I introduced a sketch of the model in my 2014 book (Lavoie, 2014). This gave rise to the first chapter of Part II (Chapter 9), the article on 'Convergence towards the normal rate of capacity utilization in neo-Kaleckian models', which I only submitted in January 2015 and which was published in Metroeconomica in 2016. This paper, along with that of Allain's (2015), has also attracted quite a bit of attention. This was not so at the beginning, however. I remember presenting the sketch of the model during the 2013 post-Keynesian summer school, organized by Eckhard Hein, Engelbert Stockhammer and the Forum for Macroeconomics and Macroeconomic Policies (FMM) in Berlin, getting the impression that the presentation had fallen on deaf ears, as it generated not even a single question. A few years later, Laura de Carvalho commented that this variant of the neo-Kaleckian model of growth and distribution was the new fashion in post-Keynesian economics, as well-known authors such as Eckhard Hein, Amitava Dutt and Tom Palley also engaged with this kind of specification! ${ }^{3}$ I also believe that this variant of the neo-Kaleckian model has helped in achieving a rapprochement between Sraffians and other post-Keynesians.

The next four chapters of Part II were all written with Won Jun Nah, now a full professor at Kyungpook National University, in Daegu, South Korea. Won Jun came as a visiting professor 
at the University of Ottawa for a full year in 2015, accompanied by his wife and his two daughters. Nah had published papers in Korean, based on DSGE models, but having taken a few courses in Marxian economics in his youth, he was searching for alternative approaches to economics. He had seen me make a presentation in Daegu, back in 2011, when I had been invited at the annual meeting of the Korean Association of Political Economy, and felt that he could find these alternatives by visiting the University of Ottawa where I was with my longtime colleague, Mario Seccareccia. Nah followed the course on the history of economic thought that Mario was giving. He also spent a considerable amount of time meticulously going through my 2014 book on post-Keynesian economics, finding many misprints and having long discussions about its contents, in particular about demand and growth regimes. Indeed, when back in Korea, he became involved in the income-led programme that was launched by the Korean government (Joo et al., 2020). Just before departing however, in the Fall of 2015, he jotted down the equations that would be needed to study what the neoKaleckian model would look like if the autonomous non-capacity-generating expenditure consisted of exports (driven by world demand) instead of consumption or government expenditures. This became the paper that we published together in the Journal of Post Keynesian Economics in 2017 (Chapter 10).

We then thought that the principle of autonomous non-capacity-generating expenditure combined with the Harrodian dynamic instability principle could be applied within many other contexts. By December 2016, we had submitted the paper that was eventually published in September 2019 in the Review of Keynesian Economics (Chapter 11), where we considered the impact of endogenous technical progress in a model with autonomous consumption growing at an exogenous rate. It took a long time for the paper to be published since it was accepted in February 2018 - a lesson for young scholars who are eager to get their works published as quickly as possible. We recovered a previous paradoxical result achieved by Cesaratto et al. (2003) in their discussion of the Sraffian supermultiplier mechanism, that is, the fact that technological change does not generate faster growth. For technical progress to have a positive impact on the growth rate of the economy, faster technical change needs to generate an increase in the growth rate of the non-capacity-creating autonomous components of effective demand. As we argued in our article, this could happen, for instance, if the accelerated pace in the introduction of novel and fashionable products induces an increase in the growth rate of autonomous consumption.

By December 2016, Won Jun had also written down the first draft of the paper that incorporated the conflicting-claims framework into the neo-Kaleckian growth model with autonomous consumption. This framework is popular among post-Keynesians to explain wage and price inflation, in particular when the real-wage target of workers is said to depend on the rate of employment. We submitted the paper in September 2017 and the article was eventually published in the 2019 December issue of Structural Change and Economic Dynamics (Chapter 12). Once again, there were some delays, as it took nearly a year for minor changes to get approved! An interesting feature of the article is that we provide simulations based on the theoretical model and some appropriate calibration which generates stability despite the presence of the Harrodian instability principle. The long-run version of the model also incorporates convergence towards a steady employment rate, in contrast to several neoKaleckian models where the issue of unemployment is not explicitly dealt with, thanks to an endogenous growth rate of the labour force. 
The fourth paper that resulted from my collaboration with Won Jun Nah took into account the distinction between direct and overhead labour, just as I had previously done in two papers of Part I, but this time while considering autonomously growing consumption expenditures and with the addition of the Harrodian dynamic instability principle in the long-run version. As readers may guess by now, or as they will find out when they will read my 2017 piece in the European Journal of Economics and Economic Policy (Chapter 5), I thought overhead labour and target-return pricing played a crucial part in understanding fluctuations in the profit share and hence had to be studied within the context of non-capacity generating autonomous expenditures. I had suggested the idea to Won Jun in July 2017, spurred by the completion, within the EPOG programme at the University of Paris 13, of the Master thesis of a student of mine, Lílian Nogueira Rolim, who dealt with the econometric consequences of overhead labour for the assessment of wage-led demand. ${ }^{4}$ By October we had a draft with the main equations. The paper was eventually submitted to the Cambridge Journal of Economics, but the editors and the referees thought the relevance to equations ratio was too low. A simplified version of the paper, where we assumed an exogenous normal rate of utilization instead of an endogenous one, thus perhaps making the paper less controversial, was eventually submitted to and published in 2020 in the Review of Political Economy (Chapter 13). An interesting feature of the paper is that while an increase in the relative remuneration of overhead managerial labour has no certain effect on economic activity in the short run, increased inequality in wage distribution leads to a definite fall in the average growth rate of the economy during the traverse to the new long-run equilibrium.

The last paper of Part II (Chapter 14) was written with Brett Fiebiger, an Australian who was a post-doctoral scholar at the University of Ottawa for nine months, thanks to grants from the Institute for New Economic Thinking (INET) and the Social Sciences and Humanities Research Council of Canada that my colleague Mario Seccareccia had managed to obtain in the early 2010s to study the political economy of new fiscalism. When, later, I also got a grant from INET to study central banking and its crises, we once more solicited Brett's help. I think it is fair to say that both Brett and I greatly benefitted from this interaction, as we continued our collaboration much beyond his stay in Ottawa, having published together no less than five articles. In the meantime, Brett got very much interested in the empirical issues surrounding the role of non-capacity-generating autonomous expenditures, or more precisely what he calls semi-autonomous expenditures. As said earlier, this topic attracted the attention of many wellknown post-Keynesians, but it also attracted the attention of several detractors. With working papers and submissions flying back and forth, Neri Salvadori and Heinz Kurz, as the editors of Metroeconomica, decided to devote a special issue to the topic. The paper written with Brett Fiebiger, devoted to a mixture of theoretical and empirical approaches to the role of what we called non-capacity-generating semi-autonomous expenditures, was accepted in September 2017, but as the special issue had to await laggards, it appeared in Metroeconomica in May 2019. The paper can be considered to be a critique of Harrodian or Goodwinian critics (such as Peter Skott) of the neo-Kaleckian approach. The paper also underlines the importance of residential construction - hence household investment - in generating economic activity, at least in the US economy. The companion paper that we refer to as Fiebiger (in press) in the article, was finally published as Fiebiger (2018), and is certainly worth reading as it demonstrates that corporate investment follows (and does not accompany) increases in 
economic activity, thus also showing the relevance of the Sraffian supermultiplier and its induced investment.

\section{Part III: Two-sector growth models}

Besides Mario Seccareccia and I, two full professors at the University of Ottawa in the 1980s had some relationship with post-Keynesian economics. Anna Koutsoyiannis was part of the staff for a short while. She had written a terrific second-year microeconomics textbook, which contained several chapters devoted to limit-entry pricing and to what she called average pricing, as well as a critique of marginal pricing (Koutsoyiannis, 1975). Her textbook thus dealt with the ideas of authors such as Sylos-Labini, Hall and Hitch, Cyert and March, Lanzillotti, and Andrews, the latter having been her colleague at the University of Lancaster. The second professor was Jacques Henry. He had been trained as a neoclassical development economist, but he met his Damascus moment when he spent a sabbatical in the Sahel desert, realizing that their inhabitants were thoughtful and wise individuals despite following none of the development models of neoclassical economics. He then searched for alternative models, found Sraffian economics and later the rest of post-Keynesian economics, in part through discussions with Mario and I. In 1985, he wrote a working paper, called 'Traverse as a process of reproportioning', which was presented at a conference held at the University of Ottawa in 1987. The paper was intended to be part of a book devoted to traverse analysis, but for reasons that we could not elucidate, the paper was not included in the book, each of the three editors blaming the others for the refusal. Jacques Henry passed away at the age of 55 in 1989, at about the same age and same time as Alfred Eichner, both deaths being dramatic losses for post-Keynesian economics. Jacques had left his traverse paper aside, and I decided to resurrect it, as I felt that his draft was much more original than the editors of the book had thought and hence merited an effort to revise it in the hope of obtaining proper publication.

Sraffian economics, at least at the time, only dealt with stationary or steady states. It was Hicks (1965) who first attempted to analyze how an economy would transit from one equilibrium to another (with a lower or higher growth rate of the labour force) within a twosector Sraffian model with fixed coefficients, producing a consumption good and a fixed capital good utilized in both sectors - a specification which can also be found in Robinson (1956). His traverse, and the one analyzed in the first article of Part III (Chapter 15), published in 1997 in Structural Change and Economic Dynamics, can be dubbed a neoclassical traverse, because it analyzes the transition under the condition that full employment of labour and full capacity utilization in both sectors are being maintained. ${ }^{5}$ For this to happen, there has to be a reproportioning of the capital stock and of the labour force, which justifies the title of the article, 'The Hicksian traverse as a process of reproportioning'. Both Hicks and Henry argued that all the interesting action in economics occurs during the transition, during the traverse, in other words, in historical time (and not in logical time at the steady state) as Joan Robinson would put it. While others had previously shown, through stability analysis, that for the traverse to be possible, the capital-to-labour ratio in the consumption sector had to be higher than in the investment sector, the originality of our paper was to describe graphically the actual path followed by both quantities and prices, both in the stable cases and in the unstable cases. In particular, the consequences of the unsuccessful traverses were mathematically and graphically spelled out, with in one case fewer and fewer consumption goods being produced and in the other with fewer and fewer capital goods being produced. We also showed that the 
price traverse resulted from the quantity traverse required for reproportioning, prices changing to ensure that aggregate demand would match the quantities being supplied from one period to the next.

In some sense, the second paper of Part III (Chapter 16), titled 'Pasinetti's vertically hyperintegrated sectors and natural prices', published in a 1997 issue of the Cambridge Journal of Economics, also deals with transition and reproportioning of the production structure. The title is perhaps misleading as it deals with two views of vertical integration - Pasinetti's view and what I called the standard view. The paper arose from my interaction with my former undergraduate teacher, Tom Rymes (also a tennis partner), who had his own approach to vertical integration - which I called the standard view. The purpose of the paper, as in many other instances when I have written papers, was to clarify my own views on the subject and to provide a pedagogical understanding of Pasinetti's concept of hyper-vertically integrated labour coefficients. ${ }^{6}$ I thus designed the simplest model that could handle structural change, that is, a three-sector model, with two sectors producing consumption goods and one sector producing a basic good - the machines used in all three sectors. There is thus a clear interdependence between the three sectors, which produces many problems when the two consumption sectors are not growing at the same rate. I retrieve results which are similar to those observed in the previous article, that is, growth is unsustainable when the two consumption sectors grow at exogenously-given growth rates. I compared this model with the equivalent model that arose from Pasinetti's view of vertical integration and his efforts to get around the stability problems provoked by this interdependence, by assuming that each consumption sector has access to its own industrial source of machines, as if the investment sector is composed of two firms, each feeding itself and only one consumption sector. The cost to pay to avoid the interdependence is that when computing natural prices (where the profit rate is equal to the growth rate), following Pasinetti, the same machine needs to be valued at two different prices, depending on the consumption sector that it is associated with. The only other way out is to assume within the standard view of vertical integration that there is flexibility in the utilization of the capital stock, that is, firms dispose of excess reserves of capacity with endogenous rates of capacity utilization.

And this is exactly what was assumed in the next paper, one also published in 1997, this time in the Manchester School of Economic and Social Studies (Chapter 17). The paper looks at what happens in the traverse in the case of a two-sector model whose structure is similar to the one used to analyze the Hicksian traverse, but without assuming full employment, assuming instead fixed prices, target-return pricing (without uniform rates of profit) and endogenous rates of utilization. In other words, the paper examines reproportioning during the traverse in a two-sector neo-Kaleckian model of growth and distribution. The article arose as a result of the preliminary work that was conducted in his major paper by an MA student at the University of Ottawa, Pablo Ramírez-Gastón. Investment in each sector is assumed to be a simple function of the rate of capacity utilization of the sector, so this is what determines the growth of the economy. In contrast to the Hicksian/Sraffian model, the successful realization of the traverse does not depend on the investment sector being less capital-intensive than the consumption sector. Also in contrast to the Hicksian/Sraffian case, in a successful traverse, the proportion of capital held in the investment sector is not necessarily positively tied to the rate of capital accumulation. The cause of this is the endogeneity of the rate of utilization, as reflected by a fundamental equality, given by $g=u_{i} / a_{k i}(1+\kappa)$, where $g$ is the overall rate of 
capital accumulation, $u_{i}$ and $a_{k i}$ are the rate of utilization and the capital-to-capacity ratio of the investment sector, while $\kappa$ is the proportion of machines held in the consumption sector relative to the machines found in the investment sector. If the rate of utilization is stuck at its normal level, at constant technical coefficients, a higher growth rate must necessarily be associated with a lower kappa.

Except for Amitava Dutt (1988) and the paper described above, until very recently, virtually no one tackled the topic of the two-sector Kaleckian model of growth and distribution. Along with Fujita (2019), Nishi (2020) and Fanti and Zamparelli (2021), the last paper of Part III is one of the few articles which dared to do so. This is the paper that I wrote with Jung Hoon Kim, on the basis of a chapter of his doctoral dissertation at the University of Ottawa back in 2007 (Chapter 18). The article was published in 2017 in the Korean Economic Review. As in the previous paper, it relies on target-return pricing, but with an investment function that incorporates both the rate of utilization and the rate of profit, and it examines the traverse to the new long-run equilibrium position when changes are made to the propensity to save out of profits or to the target rates of return of either sector. It also examines a series of different closures, in the same spirit as Dutt's (1988) paper. One such closure is based on the assumption that the rate of accumulation in the investment sector is equal to the rate of growth of the consumption sector, modulated by the discrepancy between the profit rates of the two sectors. With such a variant, there is convergence towards a uniform rate of profit, provided the speed of adjustment of profit rate differentials is smaller than the propensity to save out of profits.

A fully-adjusted position, as Vianello (1985) called them, could be achieved if in addition it is assumed that target rates of return are raised whenever the actual profit rate exceeds the target rate of return. With this modification, the rates of utilization of both sectors converge to their normal value. The paradox of thrift still holds because a higher propensity to save leads to a lower growth rate. However, this last closure links up with the models described in Part II, because an increase in real wages will only lead to a temporary increase in the growth rate of the economy and in the rate of capacity utilization during the transition towards the new steady state. As in the models of Part II with autonomous non-capital-generating expenditures, the initial imposition of higher real wages will induce a level (instead of a growth rate) of economic activity and productive capacity which is higher than if no such change had been imposed. The overall lesson taken from this last study is that the results obtained with the help of these sophisticated two-sector models are roughly isomorphic to the results achieved with simpler one-sector models, thus justifying their use.

\section{Conclusion}

Post-Keynesian authors have given much attention to the issues connecting growth and income distribution. Today, income distribution - income and wealth inequality - is very much a topic of interest among scholars of all horizons. Growth, by contrast, is a contested terrain, with many authors looking for ways to slow down growth, or even achieve zero growth or degrowth, instead of speeding up growth in the hope of achieving full employment, because of ecological concerns and the carbonization of the economy. Along with many postKeynesians of my generation, I have not given much thought to the degrowth possibilities or necessities. It should be pointed out, however, that several ecological economists are now using the tools of post-Keynesian economics, Kaleckian, Sraffian or Goodwinian models and the stock-flow consistent approach, to develop alternative macroeconomic models that 
incorporate environmental issues without relying on standard mainstream assumptions. As our economies will transition towards a greener economy, the concept of the traverse, as described in some of the articles of Part III, will become ever relevant. ${ }^{7}$ A number of postKeynesians are already engaged in this search, some within the confines of agent-based modelling.

\section{Notes}

1. I tackled again this issue in Lavoie $(2008,2018)$.

2. In particular, I offered an examination and critique of White's (1996) investment function and mechanism in Lavoie (1999).

3. There was a small algebraic error in the computations of the determinant and the trace of the Jacobian, which was corrected by Skott (2017).

4. A quite different version of her work was eventually published as Rolim (2019).

5. A somewhat revised version of the paper, with much cleaner figures, was published in French in Henry and Lavoie (2002).

6. I returned to this topic in Seppecher et al. (2018), in an agent-based model with three industries making consumption, intermediate and fixed capital goods, where markups were randomized, showing that the prices of the consumption good ended up being very close to Pasinetti's natural price, proportional to the unweighted sum of the direct, indirect and hyper-indirect labour coefficients.

7. To give a single example, see Nguyen-Huu and Pottier (2020) on energy transition.

\section{References}

Allain, O. (2015), 'Tackling the instability of growth: a Kaleckian-Harrodian model with an autonomous expenditure component', Cambridge Journal of Economics, 39 (5), September, 1351-71.

Araujo, J.T. (1995), 'Kaldor's neo-Pasinetti theorem and the Cambridge theory of distribution', Manchester School of Economics and Social Studies, 63 (3), September, 311-17.

Arestis, P. (2009), 'New Consensus macroeconomics and Keynesian critique', in E. Hein, T. Niechoj and E. Stockhammer (eds), Macroeconomic Policies on Shaky Foundations: Whither Mainstream Economics?, Marburg: Metropolis, pp. 165-86.

Asimakopulos, A. (1975), 'A Kaleckian theory of income distribution', Canadian Journal of Economics, 8 (3), August, 313-33.

Bhaduri, A. and S. Marglin (1990), 'Unemployment and the real wage: The economic basis for contesting political ideologies', Cambridge Journal of Economics, 14 (4), December, 375-93.

Bortis, H. (1997), Institutions, Behaviour and Economic Theory: A Contribution to Classical-Keynesian Political Economy, Cambridge: Cambridge University Press.

Cesaratto, S., F. Serrano and A. Stirati (2003), 'Technical change, effective demand and employment', Review of Political Economy, 15 (1), 33-52.

Davidson, P. (1968), 'The demand and supply of securities and economic growth and its implications for the KaldorPasinetti versus Samuelson-Modigliani controversy', American Economic Review, 58 (2), May, 252-69.

Dejuán, Ó. (2013), 'Normal paths of growth shaped by the supermultiplier', in E.S. Levrero, A. Palumbo and A. Stirati (eds), Sraffa and the Reconstruction of Economic Theory: Volume Two: Aggregate Demand, Policy Analysis and Growth, Basingstoke: Palgrave Macmillan, pp. 139-57.

Duménil, G. and D. Lévy (1995), ‘A post-Keynesian long-term equilibrium with equalized profit rates', Review of Radical Political Economics, 27 (2), 135-41.

Duménil, G. and D. Lévy (1999), 'Being Keynesian in the short term and classical in the long term: The traverse to classical long-term equilibrium', Manchester School of Economics and Social Studies, 67 (6), December, 684-716.

Dutt, A.K. (1984), 'Stagnation, income distribution and monopoly power', Cambridge Journal of Economics, 8 (1), March, 25-40.

Dutt, A.K. (1988), 'Convergence and equilibrium in two sector models of growth, distribution and prices', Journal of Economics, 48 (2), 135-58.

Dutt, A.K. (1992), 'Stagnation, growth and unproductive activity', in J.B. Davis (ed.), The Economic Surplus in Advanced Economics, Aldershot, UK and Brookfield, VT, USA: Edward Elgar Publishing, pp. 91-113.

Fanti, L. and L. Zamparelli (2021), 'The paradox of thrift in a two-sector Kaleckian growth model', Metroeconomica, 72 (3), July, 526-38.

Fiebiger, B. (2018), 'Semi-autonomous household expenditures as the causa causans of postwar US business cycles: The stability and instability of Luxemburg-type external markets', Cambridge Journal of Economics, 42 (1), January, 155-75. 
Fontana, G. and M. Setterfield (eds) (2009), Macroeconomic Theory and Macroeconomic Pedagogy, Basingstoke: Palgrave Macmillan.

Freitas, F. and F. Serrano (2015), 'Growth rate and level effects: The stability of the adjustment of capacity to demand and the Sraffian supermultiplier', Review of Political Economy, 27 (3), July, 258-81.

Fujita, S. (2019), 'Mark-up pricing, sectoral dynamics, and the traverse process in a two-sector Kaleckian economy', Cambridge Journal of Economics, 43 (2), March, 465-79.

Godley, W. and M. Lavoie (2007), Monetary Economics: An Integrated Approach to Credit, Money, Income, Production and Wealth, Basingstoke: Palgrave Macmillan.

Harris, D.J. (1974), 'The price policy of firms, the level of employment and distribution of income in the short run', Australian Economic Papers, 13 (22), June, 144-51.

Hein, E. (2008), Money, Distribution Conflict and Capital Accumulation: Contributions to Monetary Analysis, Basingstoke: Palgrave Macmillan.

Hein, E., M. Lavoie and T. Van Treeck (2011), 'Some instability puzzles in Kaleckian models of growth and distribution: A critical survey', Cambridge Journal of Economics, 35 (1), May, 587-612.

Hein, E., M. Lavoie and T. Van Treeck (2012), 'Harrodian instability and the normal rate of capacity utilization in Kaleckian models of distribution and growth - a survey', Metroeconomica, 63 (1), March, 39-69.

Henry, J. and M. Lavoie (2002), 'La traverse de Hicks dans son modèle horizontal bisectoriel: Le réaménagement de la structure productive', L'Actualité économique, 78 (1), March, 87-114.

Hicks, J.R. (1965), Capital and Growth, Oxford: Oxford University Press.

Joo, S., K. Lee, W.J. Nah, S.M. Jeon and D.H. Joe (2020), The Income-Led Growth in Korea: Status, Prospects and Lessons for Other Countries, Sejong: Korea Institute for International Economic Policy.

Kahn, R.F. (1972), 'Notes on the rate of interest and the growth of firms', in R.F. Kahn, Selected Essays on Employment and Growth, Cambridge: Cambridge University Press, pp. 208-32.

Koutsoyiannis, A. (1975), Modern Microeconomics, London: Macmillan.

Kurz, H.D. (1990), 'Technical change, growth and distribution: A steady state approach to unsteady growth', in H.D. Kurz, Capital, Distribution and Effective Demand: Studies in the Classical Approach to Economic Theory, Cambridge: Polity Press, pp. 210-39.

Lanzillotti, R.F. (1958), 'Pricing objectives in large companies', American Economic Review, 48 (5), December, 921-40.

Lavoie, M. (1987), Macroéconomie: Théorie et controverses postkeynésiennes, Paris: Dunod.

Lavoie, M. (1992), Foundations of Post-Keynesian Economic Analysis, Aldershot: Edward Elgar.

Lavoie, M. (1993), 'A post-classical view of money, interest, growth and distribution', in G. Mongiovi and C. Ruhl (eds), Macroeconomic Theory: Diversity and Convergence, Aldershot: Edward Elgar, pp. 3-21.

Lavoie, M. (1996), 'Unproductive outlays and capital accumulation with target-return pricing', Review of Social Economy, 54 (3), Fall, 303-21.

Lavoie, M. (1999), 'Investment functions in Sraffian and Kaleckian models', Économie appliquée, 52 (1), 119-25.

Lavoie, M. (2006), 'A post-Keynesian amendment to the New Consensus on monetary policy', Metroeconomica, 57 (2), May, 165-92.

Lavoie, M. (2008), 'Neoclassical empirical evidence on employment and production laws as artefact', Revista Economía Informa, 351, March-April, 9-36.

Lavoie, M. (2014), Post-Keynesian Economics: New Foundations, Cheltenham, UK and Northampton, MA, USA: Edward Elgar Publishing.

Lavoie, M. (2018), 'Production functions, the Kaldor-Verdoorn law and methodology', in P. Arestis (ed.), Alternative Approaches in Macroeconomics: Essays in Honour of John McCombie, Basingstoke: Palgrave Macmillan, pp. 303-30.

Lavoie, M. and W. Godley (2001-02), 'Kaleckian models of growth in a coherent stock-flow monetary framework: A Kaldorian view', Journal of Post Keynesian Economics, 24 (2), Winter, 277-312.

Nguyen-Huu, A. and A. Pottier (2020), 'The Hicksian traverse revisited: Conditions for the energy transition', Structural Change and Economic Dynamics, 54, September, 102-11.

Nishi, H. (2020), 'A two-sector Kaleckian model of growth and distribution with endogenous productivity dynamics', Economic Modelling, 88, June, 223-43.

Robinson, J. (1956), The Accumulation of Capital, London: Macmillan.

Rolim, L.N. (2019), 'Overhead labour and feedback effects between capacity utilization and income distributions: Estimations for the USA economy', International Review of Applied Economics, 33 (6), 756-73.

Rowthorn, B. (1981), 'Demand, real wages and economic growth', Thames Papers in Political Economy, Autumn, $1-39$.

Rymes, T.K. (1971), On Concepts of Capital and Technical Change, Cambridge: Cambridge University Press.

Seppecher, P., I. Salle and M. Lavoie (2018), 'What drives markups? Evolutionary pricing in an agent-based stockflow consistent macroeconomic model', Industrial and Corporate Change, 27 (6), December, 1045-67.

Serrano, F. (1995), 'Long period effective demand and the Sraffian supermultiplier', Contributions to Political 
Economy, 14, 67-90.

Serrano, F. and F. Freitas (2007), 'El supermultiplicador sraffiano y el papel de la demanda efectiva en los modelos de crecimiento', Circus, 1, October, 21-37.

Skott, P. (2017), 'Autonomous demand and the Harrodian criticism of the Kaleckian model', Metroeconomica, 68 (1), February, 185-93.

Vianello, F. (1985), 'The pace of accumulation', Political Economy: Studies in the Surplus Approach, 1 (1), 69-87.

White, G. (1996), 'Classical competition, Keynesian adjustment and composite dynamics: A critical perspective', Économie appliquée, 49 (4), 5-36.

Wood, A. (1975), A Theory of Profits, Cambridge: Cambridge University Press. 
Marc Lavoie - 9781802206951 